\title{
EMPLOYEE COMMITMENT AND ORGANIZATIONAL PERFORMANCE IN SELECTED FAST FOOD OUTLETS IN OSUN STATE
}

\section{Ehimen Abiodun Ulabor ${ }^{1}$, Agelebe Ibiwunmi Bosede ${ }^{2}$}

Federal Polytechnic Ede ${ }^{1,2}$

Email: ehimena@yahoo.com ${ }^{1}$,ibiwunmiagelebe@gmail.com²

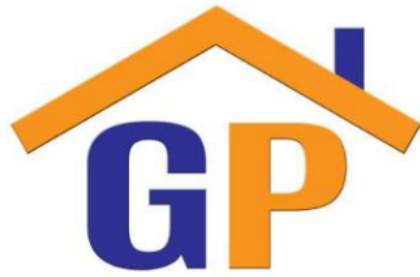

\section{Article History}

Received 20 July 2019

Revised 29 July 2019

Accepted 7 August 2019

\begin{abstract}
Purpose: This study examined the effect of employee commitment on organization performance of selected fast food outlets in Osun State. It determined how employee commitment affects staff turnover and also examined factors that affect employee commitment
\end{abstract}

Design/Research method: Primary data was used for this study; respondents were selected using convenient sampling method from the study area. Questionnaire was used to gather information. One hundred copies of questionnaire were administered to the selected respondents and ninety-six were retrieved and found useful for analysis. The data gathered were analysed using both descriptive and inferential statistics.

Finding: Findings revealed that employee commitment is significant to organization performance. Profitability, increased in sales, and increased in customers' patronage were used to measure organizational performance, and it was observed that employee commitment influence profitability; increased in sales, customers' patronage. It was observed that employee commitment affects staff turnover as revealed by the chi-square statistic $(x 2=)$. Likewise, findings showed that employee commitment could be affected by some factors such as gender, nature of work, length of service, and management style, Although, length of service and management style were not significant at $5 \%$ significance level. The study concluded that an employee commitment can influence the organization performance.

Keywords: Employee commitment, Organization performance, Staff turnover

How to Cite: Ulabor, E. A., \& Bosede, A. I. (2019). Employee commitment and organizational performance in selected fast food outlets in osun state. International Journal of Financial, Accounting, and Management, 1(1), 23-37. 


\section{INTRODUCTION}

In today's business world of high competitive environment, every organization is striving to maintain their stand so as to remain relevant in delivering of services to the consumers and to enhance profitability. Effective delivery of quality services to the consumers will not only make consumers to be loyal to the organization but also will facilitate customers' retention thereby increasing sales and profitability. Organization itself cannot achieve these goals without the duty of committed employees. Hence, it is germane for every organization to have full level of its employee commitment in order to have outstanding performance both in short and long term basis. Khan (2013) opined that organization can achieve their set objectives when competent and committed employees are engaged, this is in line with Argyris (1964), Likert (1961), and McGregor (1960) who purposed that the organizational performance is a result of the employee experience and commitment. Udu and Ameh (2016) asserted that organizational performance technically is the aggregate net performance of the individual employees in the organization, this is because the organization is the composition of the employees under it. An organization does not achieve anything on its own except the cumulative achievements of the employees that make up the organization. Employee commitment is relative to the workers' attachment to or participation in the organizations in which they are employed. Employee commitment is significant since it determines whether employees are likely to leave their jobs or improve performance.

Employee commitment is multi-dimensional in nature, encompassing workers' loyalty, their willingness to exert more effort on behalf of the organization, adherence to organizational values, and desire to remain in the organization (Meyer \& Allen, 1997). Iqra and Yahya (2013) outlined some of the indicators of a committed employee which include but not limited to lack of interest in job offers elsewhere, willingness to accept responsibility, expression of job satisfaction, willingness and ability to make useful contributions, eagerness to work with less supervision and not given to unnecessary excuses. The chances that employees will remain committed to the organization rely mainly on their level of productivity and the organization's commitment to support them. Meyer \& Alien (1991) opined that employee commitment to the organization has a positive influence on job performance. Many successful organizations are strongly committed to look after their employee needs because they belief that organization that foster employee satisfaction can secure greater employee commitment as organization battle to get the most from their existing employee in an environment characterized by skill shortages, while some organization pays little or no attention to factors that could influence the employees' commitment to their organization. Sahid and Ahzar (2013) opined that motivated, committed and proficient people are extensively valuable because they can often make things work despite less than perfect systems, in furtherance to their statement, they asserted that the answer to higher productivity in an organization lies in a larger investment in creating committed people. It worth noting that the attainment of organization objective is hinged on the significant impact both positive and negative that employees have on organizational performance and productivity (Wagar 2003). Employee commitment should be viewed as a business prerequisite. Organizations that have difficulty in retaining and replacing competent employees will find it hard to optimize performance.

Moreover, securing committed employees who are competent and ready to give in their best in the pursuit of the objectives of the organization and likewise maintaining committed 
employees by those who have found them have been parts of the problems facing most organizations with no exception to the fast food outlets. Hence, this study examined the effect of employee commitment on organizational performance; determined how employee commitment affects staff turnover and also examined factors that influence employee commitment.

\section{LITERATURE REVIEW AND HYPOTHESES DEVELOPMENT Employee Commitment}

Commitment had been said to be the nature of the relationship of the member to the system as a whole (Grusky, 1966), while Kanter (1968) defines commitment as "The willingness of social actors to give their energy and loyalty to social systems, the attachment of personality systems to social relations, which are seen as self-expressive". Hall, Schneider, and Nygren (1970) defined it as the process by which the goals of the organization and those of the individual become increasingly integrated or congruent". Porter, Steers, Mowday, \& Boulian (1974) described organizational commitment as "an attachment to the organization, characterized by an intention to remain in it; an identification with the values and goals of the organization; and a willingness to exert extra effort on its behalf. Salancik (1977) said that commitment is a state of being in which an individual become bound by his action and through these action to beliefs that sustain the activities of his own involvement, while O'Reilly and Chatman (1986) viewed it as the psychological attachment felt by the person for the organization; it will reflect the degree to which the individual internalizes or adopts characteristics or perspectives of the organization.

Employees are regarded as committed to an organization if they willingly continue their association with the organization and devote considerable effort to achieving organizational goals (Raju and Srivastava, 1994). Meyer and Herscovitch, (2001) stated that employee commitment is the psychological state that binds an employee to an organization thereby reducing the problem of employee turnover and as a mind-set that takes different forms and binds an individual to a course of action that is of important to a particular target. Cohen (2003) stated that "commitment is a force that binds an individual to a course of action of relevance to one or more targets", Miller (2003) also stated that organizational commitment is "a state in which an employee identifies with a particular organization and its goals, and wishes to maintain membership in the organization". Organizational commitment is therefore, the degree in which an employee is willing to maintain membership due to interest and association with the organization's goals and values.

According to Sharma and Bajpai (2010), employees are regarded as committed to an organization if they willingly continue their association with the organization and devote considerable effort to achieving organizational goals. The high levels of effort exerted by employees with high levels of organizational commitment would lead to higher levels of performance and effectiveness of both the individual and the organizational levels. Employee commitment is a feeling of dedication to one's employing organization, willingness to work hard for that employer, and the intent to remain with that organizational attachment of the individual to the organization (Udu \& Ameh, 2016). 
Studies had been done on different dimension of commitment, Freund and Carmeli [2003] presented a model for five general forms of employee commitment: career, affirmative, work ethic, occupational, and organizational commitment. The above five commitments are further classified into two major groups. The first category centres on commitments that affect work attitudes without reference to the organization: work ethic, career, and occupational. The second category is influenced by the organization in which the employees work: continuance and affective organizational commitment. Meyer and Allen (1997) used the tri-dimensional model to conceptualize commitment, these are: affective, continuance and normative commitments. Affective commitment relates to emotional attachment, is normally linked to a favorable working environment and relationships with the other employees (Chung-Chen \& Chih-Jen, 2013). Organizational members who are committed to an organization on an affective basis, continue working for the organization because they want to (Meyer \& Allen, 1991), and also stay with the organization because they view their personal employment relationship as congruent to the goals and values of the organization (Beck \& Wilson, 2000). Normative commitment, on the other hand, is related to obligation: employees may feel they owe the organization for being given a job when they need it most (Chung-Chen \& Chih-Jen, 2013). Continuance commitment on the other hand relates to such terms of employment as job contracts, which may make leaving the current job very costly or troublesome, it is calculative in nature because of the individual's perception or weighing of costs and risks associated with leaving the current organization (Meyer \& Allen, 1997). Meyer and Allen (1991) further stated that "employees whose primary link to the organization is based on continuance commitment remain because they need to do so. Finally, normative commitment implies a situation where an employee perceives that he is morally obliged to remain in the organization due to the benefits that the employee had gained from the organization, therefore such employee feels to reciprocate by remaining in the organization.

\section{Organizational Performance}

The concept of organizational performance is based upon the idea that an organization is the voluntary association of productive assets, including human, physical, and capital resources, for the purpose of achieving a shared purpose (Alchian \& Demsetz, 1972; Barney, 2001; Jensen \& Meckling, 1976; Simon,1976). Organizational performance can be judged by many different constituencies, resulting in many different interpretations of "successful performance". Each of these perspectives of organizational performance can be argued to be unique. Further, each organization has a unique set of circumstances, making performance measurement inherently situational (Cameron \& Whetton, 1983). Richard (2009) stated that organizational performance can be measured through three basic outcomes which are financial performance, product market performance and return to the shareholders. Performance is a set of financial and nonfinancial indicators which offer information on the degree of achievement of objectives and results (Lebans \& Euske 2006, Kaplan \& Norton, 1992)

However, for the purpose of this study, performance shall be measured on the level of customer retention, employee retention, increase sales, and increase in profitability 


\section{Employee Commitment and Organizational Performance}

Organizational performance is hinged on the performance of the employees, as no organization can exist on its own. Human being are regarded as the most valuable asset an organization can possess, as they are the one to coordinate all other forms of productive resources in order to attain optimal output. Committed employee is very germane to any organization, as found by Owens (2006) in his studies that committed employees lead to higher organizational performance and very low level of employee shift from the organization, this is also corroborated by Ivancevich (2010) that performance of an organization is directly related to commitment level of employees. Employees who are committed to their respective organization are more likely not only to remain with the organization but are also likely to exert more efforts on behalf of the organization and work towards its success and therefore are also likely to exhibit better performance than the uncommitted employees. Employee commitment can benefit organization in a number of ways such as it can improve performance; reduced absenteeism, and turnover thereby resulting in sustained productivity. Commitment to organization is positively related to such desirable outcomes as motivation (Mowday, Steers \& Porter 1979) and attendance (Mathieu \& Zajac, 1990: Steers \& Rhodes,1978) and is negatively related to outcome as absenteeism and turnover (Clegg 1983, Cotton \& Tuttle 1986). Thus increasing organization productivity (Schuler \& Jackson, 1996). Employees with high level of organizational commitment provide a secure and stable workforce (Steers 1977) and thus providing competitive advantage to the organization. The committed employee has been found to be more creative; they are less likely to leave an organization than those who are uncommitted (Porter et.al. 1974).

\section{Employee Commitment and Staff Turnover}

Employees who are more involved in their jobs are more satisfied with their jobs and more committed to their organization (Blau and Boal, 1989; Brooke and Price, 1989; Brooke, Russell \& Price, 1988; Kanungo, 1982). Allen and Meyer [1990] are among the authors who have linked work commitment and staff turnover. According to them, highly committed workers are less likely to quit the organization. They relate turnover intention to affective commitment and to a slighter degree, normative commitment. The link between continuous commitment and staff turnover intention is not consistent across studies (Chon, Sung \& Yu 1999). The same is true regarding the measurement of actual turnover, taking into consideration only affective and normative commitment, not continuance commitment (Schermerhorn, Hunt \& Osborn, 2003). Turnover intention could be described as individual's verdict to leave the current job. Turnover Intention has two types: voluntary turnover and involuntary turnover. According to the first type, employees might quit the organization intentionally because of the difficult work environment or they may have some other job offers. On the other hand, in involuntary turnover organization terminates the individual because of his inability. Unintentional turnover is from organizations side (Dess \& Shaw, 2001). A committed employee is psychologically attached to the organization and so there won't be any thought of quitting. Igbaekemen and Idowu (2014) opined that high level of employee retention indicates high level of commitment and vice-versa. 


\section{Factors Affecting Employee Commitment}

Several factors had been identified in the literature as determinants of employee commitment. Some of the identified factors include; leadership style (Lo, 2009); organizational fairness (Ponnu \& Chuah, 2010); corporate social responsibility (Ali, Rehman, Ali, Yousaf \& Zia, 2010). In the study of Maxwell and Steele [2008] among hotel managers, they identified principles that enhance the level of commitment in organizations to include high and equitable remuneration, employers' interest on their workers, a high level of cooperation in the organization, and opportunities to take part in social activities. Mathieu \& Zajac, (1990), shown that commitment has been positively related to personal characteristics such as age, length of service in a particular organization (Luthans, McCaul, \& Dodd, 1985), and marital status (John \& Taylor, 1999) and have inverse relation to the employee's level of education (Glisson \& Durick, 1988). In addition, commitment has been found to be related to such job characteristics as task autonomy (Dunham, Grube, \& Castaneda, 1994), feedback (Hutichison \& Garstka, 1996) and job challenge (Meyer, Irving, \& Allen, 1998) and certain work experiences such as job security (Yousef, 1998), promotion opportunities (Gaertner \& Nollen, 1989), training and mentoring opportunities (Scandura, 1997), and supportive and considerate leadership (DeCottis \& Summers, 1987). Hence, in examining factors that influence employee commitment, this study only considered factors such as gender, management style, the nature of job, promotion and length of service

\section{RESEARCH METHODS}

The major objective of this study was to examine the impact of employee commitment on organizational performance, hence we employed a descriptive research since we considered the relationship between two variables that is the dependent which is organizational performance and the independent variable which is employee commitment. The population for the study was the whole staff of all the fast food outlets in Osun State. However, five fast food outlets were purposively chosen as the sample area because these are the major fast food outlets in Osun State. The study used convenient sampling technique in selecting respondents, thus, 20 employees each from the five outlets giving a total of 100 respondents made up of the sample size. Primary source of data was employed for the study through the use of a structured questionnaire. The questionnaire was sectioned into four, the first section sought data on the demographic characteristics of the respondents, while the other sections asked questions relating to the research objectives. The respondents were asked to rate their level of agreement or disagreement on questions asked using five point Likert scale. From the total number of 100 copies of questionnaire administered to respondents, 96 copies were retrieved and found useful for the research analysis. Data gathered were analyzed using both descriptive and inferential statistics.

\section{DATA ANALYSIS AND INTERPRETATION OF RESULTS}

Table 1 revealed the demographic characteristics of respondents, $66.7 \%$ were female while $33.3 \%$ were male, this shows that the fast food outlets have more female working with them than the male. The age distribution shows that $8.3 \%$ were below the age of 20 years, $62.5 \%$ and $27.1 \%$ were between age $21-30$ and $31-40$ years respectively, indicating that most workers in the fast food outlets are youth. The marital status from the table revealed that larger percentage of the workers are single with $57.5 \%$ and $40.6 \%$ married while only $1 \%$ is separated. From the distribution of academic qualification of the respondents, the table 
revealed that $19.8 \%$ were SSCE/WAEC holder, $42.7 \%$ had OND/NCE, 34.4\% and $2.1 \%$ had HND/BSc and M.Sc/MBA respectively. $3.1 \%$ of the respondents had been working in fast food outlets for a period of 11-15 years, while $20.8 \%$ had been there for period between 5-10 years and $69.8 \%$ of the respondents had only been there for a period less than 5 years, this shows that larger percentage of the workers in the fast food outlets had only worked there for less than 5 years. Income range per month of the respondent revealed that larger percentage earn less than $\$ 50,000$, while $19.8 \%$ earn income between $\$ 50,000$ and $\$ 100000$ and only $4.2 \%$ earn income between $\$ 100000$ and $\$ 150000$.

Table 1: Demographic Characteristics

\begin{tabular}{|c|c|c|}
\hline \multirow{2}{*}{$\begin{array}{l}\text { Demographic } \\
\text { Sex: }\end{array}$} & Frequencies & Percent \\
\hline & & \\
\hline Male & 32 & $33.3 \%$ \\
\hline Female & 64 & $66.7 \%$ \\
\hline \multicolumn{3}{|l|}{ Age: } \\
\hline Below 20 years & 8 & $8.5 \%$ \\
\hline $21-30$ years & 60 & $63.8 \%$ \\
\hline $31-40$ years & 26 & $27.7 \%$ \\
\hline \multicolumn{3}{|l|}{ Marital Status: } \\
\hline Single & 55 & $57.9 \%$ \\
\hline Married & 39 & $41.1 \%$ \\
\hline Separated & 1 & $1.1 \%$ \\
\hline \multicolumn{3}{|c|}{ Academic Oualification: } \\
\hline SSCE/WAEC & 19 & $20.0 \%$ \\
\hline OND/NCE & 41 & $43.7 \%$ \\
\hline HND/BSc & 33 & $34.7 \%$ \\
\hline M.Sc//MBA & 2 & $2.1 \%$ \\
\hline \multicolumn{3}{|l|}{ Length of Service: } \\
\hline Less than 5 years & 67 & $74.4 \%$ \\
\hline $5-10$ years & 20 & $22.2 \%$ \\
\hline $11-15$ years & 3 & $3.3 \%$ \\
\hline \multicolumn{3}{|c|}{ Income Range per Month } \\
\hline Less than \#50000 & 70 & $75.2 \%$ \\
\hline \#50000 - \#100000 & 19 & $20.4 \%$ \\
\hline \#100000 - \#150000 & 4 & $4.3 \%$ \\
\hline
\end{tabular}

Source: Researcher's Computation, 2017

Table 2a shows a relationship between employee commitment and profitability with $\chi 2=$ 20.208 at $p$-value of .003 , also table $2 b$ revealed $\chi 2$ to be 15.364 and $p$-value of .002 , this indicates that sales in the organization could be influence by employee commitment. Likewise, table $2 \mathrm{c}$ shows $\chi 2=24.684$, $\mathrm{p}$-value $=.016$ revealing a relationship between committed employee and increase in customers' patronage but not significant at $5 \%$ level of significance. Hence, since the p-value is less than 0.05 significance level, we can conclude that there is a relationship between employee commitment and profitability, customers' patronage and also increase in sale. Therefore, employee commitment can determine 
organizational performance this corroborates the findings of Iyancevich (2010), who opined that performance of an organization is directly related to commitment level of employees.

Table 2a: Employee Commitment and Organizational Profitability

Chi-Square Tests

\begin{tabular}{|l|r|r|r|}
\hline & \multicolumn{1}{|c|}{ Value } & df & $\begin{array}{c}\text { Asymp. Sig. } \\
\text { (2-sided) }\end{array}$ \\
\hline Pearson Chi-Square & $20.208^{\mathrm{a}}$ & 6 & .003 \\
Likelihood Ratio & 16.730 & 6 & .010 \\
Linear-by-Linear & 6.193 & 1 & .013 \\
Association & 96 & & \\
N of Valid Cases & & \\
\hline
\end{tabular}

a. 4 cells $(33.3 \%)$ have expected count less than 5 . The minimum expected count is .29 .

Table 2b: Employee Commitment and Increase in Sales

Chi-Square Tests

\begin{tabular}{|l|r|r|r|}
\hline & \multicolumn{1}{|c|}{ Value } & df & $\begin{array}{c}\text { Asymp. Sig. } \\
\text { (2-sided) }\end{array}$ \\
\hline Pearson Chi-Square & $15.364^{\mathrm{a}}$ & 3 & .002 \\
Likelihood Ratio & 17.409 & 3 & .001 \\
Linear-by-Linear & .098 & 1 & .754 \\
Association & 95 & & \\
N of Valid Cases & & \\
\hline
\end{tabular}

a. 2 cells $(25.0 \%)$ have expected count less than 5 . The minimum expected count is 3.15 .

Table 2c: Employee Commitment and Increased Customer's Patronage Chi-Square Tests

\begin{tabular}{|l|r|r|r|}
\hline & \multicolumn{1}{|c|}{ Value } & \multicolumn{1}{c|}{ df } & $\begin{array}{r}\text { Asymp. Sig. } \\
\text { (2-sided) }\end{array}$ \\
\hline Pearson Chi-Square & $24.684^{\mathrm{a}}$ & 12 & .016 \\
Likelihood Ratio & 25.440 & 12 & .013 \\
Linear-by-Linear & 1.144 & 1 & .285 \\
Association & 94 & & \\
N of Valid Cases & & \\
\hline
\end{tabular}

a. 14 cells $(70.0 \%)$ have expected count less than 5 . The minimum expected count is .26 .

Table 3 revealed that committed employees are not likely to leave the organization, this is depicted in the result as we have $\chi 2$ to be 40.777 and p-value as 0.001 , this indicates that as p-value is less than 0.005 , then there is a statistical significance of employee commitment to staff turnover, this corroborates the work of Allen and Meyer (1990) who opined that highly committed workers are less likely to quit the organization. Thus, a committed employee is less likely to quit an organization. 
Table 3: Employee Commitment and Staff Turnover

Chi-Square Tests

\begin{tabular}{|l|r|r|r|}
\hline & Value & df & \multicolumn{2}{|c|}{$\begin{array}{c}\text { Asymp. Sig. } \\
\text { (2-sided) }\end{array}$} \\
\hline Pearson Chi-Square & $40.777^{\mathrm{a}}$ & 16 & .001 \\
Likelihood Ratio & 44.710 & 16 & .000 \\
Linear-by-Linear & .141 & 1 & .707 \\
Association & 94 & & \\
N of Valid Cases & & \\
\hline
\end{tabular}

a. 19 cells $(76.0 \%)$ have expected count less than 5 . The minimum expected count is 13 .

Table 4a depicts that gender can influence employee commitment as $\chi 2=60.742$, p-value $=$ .000 , this shows that there is significance relationship between employee commitment and gender, this is in line with the finding of Chung-Chen and Chih-Jen (2013) who revealed that there is a significant relationship between sex and employee commitment and also with the studies of Allen and Meyer (2003) who stated that female are more committed than male, hence we can conclude that gender can influence employee commitment.

Table $4 \mathrm{~b}$ revealed that nature of work can influence employee commitment to an organization as $\chi^{2}=60.742$, p-value $=.000$, hence since the $\mathrm{p}$-value is less than $5 \%$ then we conclude that the nature of work is significant to commitment of employees, thus, it can influence employee commitment. Also table $4 \mathrm{c}$ indicated that length of service is statistically significant to employee commitment since $\chi 2=26.854$, p-value $=.043$. However, table $4 \mathrm{~d}$ revealed a positive relationship between employee commitment and management style but not statistically significant as $\chi 2=24.777$, p-value $=.074$.

Table 4a: Employee Commitment and Gender

Chi-Square Tests

\begin{tabular}{|l|r|r|r|}
\hline & Value & df & \multicolumn{2}{|c|}{$\begin{array}{c}\text { Asymp. Sig. } \\
\text { (2-sided) }\end{array}$} \\
\hline Pearson Chi-Square & $60.742^{\mathrm{a}}$ & 16 & .000 \\
Likelihood Ratio & 56.509 & 16 & .000 \\
Linear-by-Linear & 12.567 & 1 & .000 \\
Association & 94 & & \\
N of Valid Cases & & \\
\hline
\end{tabular}

a. 19 cells $(76.0 \%)$ have expected count less than 5 . The minimum expected count is .38 .

Table 4b: Employee Commitment and Nature of Work

Chi-Square Tests

\begin{tabular}{|l|r|r|r|}
\hline & Value & \multicolumn{1}{|c|}{ df } & $\begin{array}{c}\text { Asymp. Sig. } \\
\text { (2-sided) }\end{array}$ \\
\hline Pearson Chi-Square & $48.706^{\mathrm{a}}$ & 16 & .000
\end{tabular}




\begin{tabular}{|l|r|r|r|} 
Likelihood Ratio & 36.494 & 16 & .002 \\
Linear-by-Linear & 6.809 & 1 & .009 \\
Association & 94 & & \\
N of Valid Cases & & \\
\hline
\end{tabular}

a. 19 cells $(76.0 \%)$ have expected count less than 5 . The minimum expected count is .32 .

Table 4c: Employee Commitment and Length of Service

Chi-Square Tests

\begin{tabular}{|l|r|r|r|}
\hline & \multicolumn{1}{|c|}{ Value } & \multicolumn{1}{c|}{ df } & $\begin{array}{r}\text { Asymp. Sig. } \\
\text { (2-sided) }\end{array}$ \\
\hline Pearson Chi-Square & $26.854^{\mathrm{a}}$ & 16 & .043 \\
Likelihood Ratio & 30.077 & 16 & .018 \\
Linear-by-Linear & 4.808 & 1 & .028 \\
Association & 94 & & \\
N of Valid Cases & & \\
\hline
\end{tabular}

a. 20 cells $(80.0 \%)$ have expected count less than 5 . The minimum expected count is .45 .

Table 4d: Employee Commitment and Management Style

Chi-Square Tests

\begin{tabular}{|l|r|r|r|}
\hline & Value & df & $\begin{array}{r}\text { Asymp. Sig. } \\
\text { (2-sided) }\end{array}$ \\
\hline Pearson Chi-Square & $24.777^{\mathrm{a}}$ & 16 & .074 \\
Likelihood Ratio & 28.620 & 16 & .027 \\
Linear-by-Linear & .140 & 1 & .708 \\
Association & 93 & & \\
N of Valid Cases & & \\
\hline
\end{tabular}

a. 19 cells $(76.0 \%)$ have expected count less than 5 . The minimum expected count is .19 .

\section{CONCLUSION AND RECOMMENDATION}

The study discovered a relationship between employee commitment and organizational performance. Results revealed that commitment by employee can trigger increased sales, increased profitability, encouraged persistent customers' patronage and since these are the factors that determines organizational performance, then we can infer that employee commitment is germane to the performance of an organization and in particular the fast food outlets. Moreso, findings show that when an employee is committed to organization, such employee is less likely to quit an organization. Likewise, the result indicated that factors such as gender type, nature of work, length of service and management style can influence employee commitment in fast food outlets.

Hence, inferring from the findings and conclusion derived from this study, thus we recommend that organizations should pay attention to factors that could make the employee 
give a total commitment to their job as this will boast the performance of the organization. Each stakeholder in an organization have different needs, employees should ensure that their goals are in congruence with the organization, and must then always be willing in discharging their duty committedly so as to encourage the organization in meeting their needs too.

However, the limitation of this study is that the study made use of questionnaire as a means of collecting data and there is likelihood that the respondents might not be totally truthful in the responses supplied. Also, only factors such as gender, length of service, nature of work and management style were considered in this study as factors that could influence employee commitment, further study could look into other factors.

\section{REFERENCES}

Alchian, A., \& Demsetz, H. (1972). Production, information costs, and economic organization. American Economic Review, 62: 777-795.

Ali I., Rehman K., Ali S.I., Yousaf J. \& Zia M. (2010). Corporate Social Responsibility Influences, Employee Commitment and Organizational Performance. African Journal of Business Management. 4(12), 2796-2801.

Argyris, C. (1964). Integrating the individual and the organization. New York: Wiley.

Barney, J. B. (2002). Gaining and sustaining competitive advantage (2nd ed.). Upper Saddle River, NJ: Pearson Education, Inc.

Blau, P. (1964). Exchange and power in social life. New York: John Wiley \& Sons.

Brooke P. P., Russell D. W. \& Price J. L. (1988). Discuss validation of measures of job satisfaction, job involvement and organizational commitment", J. Appl. Psychol. 73 (2), 139-145.

Brooke, P. P., \& Price J. L. (1989). The determinants of employee absenteeism: An empirical test of a causal model. J. Occup. Psychol. $62: 1-19$.

Cameron, \& D. A. Whetten, D. A. (1983). Organizational Effectiveness: A Comparison of Multiple Methods: 1-24. New York: Academic Press.

Chon, K. S., Sung, K. \& Yu, L. (1999). The International Hospitality Business: Management and Operations, Routledge, New York.

Chung-Chen, L. \& Chih-Jeh, C. (2013). The Relationship between Employee Commitment and Job Attitude and its Effect on Service Quality in the Tourism Industry. American Journal of Industrial and Business Management 3, 196-208

Cohen, A. (2003). Multiple commitments at work: An integrative approach. Hillsdale, NJ: Lawrence Erlbaum. 
Cotton, J., \& Tuttle, J. (1986). Employee turnover: a meta-analysis and review with implication for research. Academy of Management Review, 11 (1), 55-70.

DeCotii, T. A., \& Summers, T. P. (1987). "A path analysis of a model of the antecedents and consequences of organizational commitment”. Human Relations, 40(7), 445-470.

Dess, G. D. \& Shaw, J. D. (2001). Voluntary turnover, social capital, and organizational performance, Acad. Manage. Rev. 26 (3): pp 446-56.

Dunham, R., Grube, J., \& Castaneda , M. (1994). Organizational Commitment: The utility of an integrative definition. Journal of Applied Psychology, 79, 370-380. http://dx.doi.org/10.1037/0021-9010.79.3.370

Freund, A. \& Carmeli, A. (2003). An Empirical Assessment: Reconstruct Model for Five Universal Forms of Work Commitment," Journal of Managerial Psychology, Vol. 18, No. 7, 708-725. doi:10.1108/02683940310502403

Gaertner, K., \& Nollen S. (1989). Career experiences, perceptions of employment practices, and psychological commitment to the organization. Human Relations, 42, 975-991. http://dx.doi.org/10.1177/001872678904201102

Glisson, C. \& Durick, M. (1988).Predictors of job satisfaction and organizational commitment in human service organizations. Administrative Science Quarterly, 33 (1), 61-81.

Grusky (1966), Career mobility and organizational commitment, Administrative Science Quarterly, 10,488 503.

Hall, D. T., Schneider, B. \& Nygren, H. T. (1970) Personal factors in organizational identification, Administrative Science Quarterly, 15, 176-189.

Igbaekemen, G. O. \& Idowu, O. A. (2014). The Impact of Organizational Commitment on Employees Productivity: A Case Study of Nigeria Brewery Plc. Impact International Journal of Research in Business Management (IMPACT:IJRBM) ISSN(E): 2321 - 886X $\operatorname{ISSN}(P)$ : 2347-4572, Issue 9, $107-122$.

Iqra, A., Yahya, R. \& Tahira, U. (2013). "Effect of Organizational Learning and Knowledge Management Practices of Organizational Performance", J. Basic and Appl. Sci. Res. pp: 3(5): 34-39.

Ivancevich, J. M. (2010). Human Resource Management-11/E.

Jensen, M., \& Meckling, W. (1976). Theory of the firm: Managerial behavior, agency costs, and ownership structure. Journal of Financial Economics: 305-360. 
Kanter, R. M. (1968). Commitment and social organization: A study of commitment mechanisms in utopian communities. American Sociological Review, 33,499-517.

Kanungo. R. (1982). Measurement of job and work involvement, J. Appl. Psychol. 67: 341349.

Kaplan, R. S. \& Norton, D. P. (1993). Putting the Balanced Scorecard to Work, Harvard Business Review, September-October, pp. 134-147

Khan, H., Razi, A., Ali, S.A. \& Asghar, A. (2013). A Study on Relationship Between Organizational Job Commitment, and its Determinants among (CSRS and Managerial Level Employees of Pakistan (Telecommunication Sector), Interdisciplinary $J$. Contemporary Res. Bus. 3(11): 269-284.

Lebans, M., Euske, K. (2006), "A conceptual and operational delineation of performance", Business Performance Measurement, Cambridge University Press.

Likert, R. L. (1961). The human organization. New York: McGraw-Hill.

Lo M., Ramayah T. \& Min H. W. (2009). Leadership styles and Organizational Commitment: A Test on Malaysia Manufacturing Industry. African Journal of Marketing Management. 1(6),13

Luthans, F., McCaul, H. S. \& Dodd, N. G. (1985). Organizational commitment: A comparison of American, Japanese and Korean employees. The Academy of Management Journal, 28 (1), 213-219.

Mathieu, J. E., \& Zajac, D. M. (1990). A review and meta-analysis of the antecedents, correlates, and consequences of organizational commitment. Psychological Bulletin, 108 ,2, 171-194.

Maxwell, G. \& Steele, G. (2008). Organizational commitment: a study of managers in hotels, International Journal of Contemporary Hospitality Management, Vol. 15, No. 7, 362369. doi:10.1108/09596110310496006

McGregor, D. (1960). The human side of enterprise. New York: McGraw-Hill

Meyer J. P. \& Allen, N. J. (1991). A three component conceptualization comment. Human Resource Management Review 61-89.

Meyer, J. P., \& Allen, N. J. (1997). Commitment in the workplace: theory, research, and application. Thousand Oaks. Sage Publication

Meyer, J.P. \& Herscovitch, L. (2001). commitment in the work place: toward a general model. Human Resource Manage. Rev. 11(3): 299-326. 
Miller, D. L. (2001): The people make the process: commitment to employees, decision making, and performance. Int. Journal of Management,11::163-18

Mowday R. T., Steers R. M. \& Porter L. M. (1979). The measurement of organizational commitment. Journal of Vocational Behaviour. 14, 224-247.

O'Reilly, C. A., \& Chatman, J. (1986). Organizational commitment and psychological attachment: the effect of compliance, identification and internalization on prosocialbehavior, Journal of Applied Psychology, 71, 492-499.Of Organizational Behavior, 23, 257-266.

Owens, P. L. (2006). One more reason not to cut your training budget: The relationship between training and organizational outcomes. Public Personnel Management, 35(2): 163-171.

Ponnu C.H. \& Chuah C. C. (2010). Organizational commitment, organizational justice and employee turnover in Malaysia. African Journal of Business Management. 4(13), 26762692.

Porter L. W., Steers R. M., Mowday R. T. \& Boulian P. V. (1974). Organizational commitment, job satisfaction and turnover among psychiatric technicians. Journal of Applied Psychology. 59, 603-609.

Raju, P. M. \& Srivastava, R. C. (1994), "Factors contributing to commitment to the teaching profession”, International Journal of Educational Management, Vol. 8(5).

Richard (2009): Measuring organizational performance: towards methodological best practice. Journal of Management.

Salancik, G. R. (1977), Commitment and the control of organizational behaviour and belief, New direction for organizational behaviour, 1-54, Chicogo:St.Clair

Scandura, T. A. (1997). Mentoring and organizational justice. An empirical investigation.

Schermerhorn, J. R., Hunt, J. G. \& Osborn, R. N. (2003). Organizational behavior," 8th Edition, John Wiley \& Sons, Hoboken.

Schuler, R. S., \& Jackson, S. E. (1996). Human resource Management: Positioning for the 21 st century, sixth ed., New York: West Publication Company.

Shahid, A \& Azhar, S. M. (2013). Gaining employee commitment: linking to organizational effectiveness. Journal of Management Research, ISSN 19211 -899X, Vol. 5 (1).

Sharma, J.P. \& Bajpai, N. (2010) Organizational commitment and its impact on job satisfaction of employees. a comparative study in public and private sector in India; Int. Bulletin of Bus. Admin. 9:7-19 
Simon, H. A. (1976). Administrative Behavior (3rd ed.). New York: Macmillan.

Steers, R. M. (1977). Antecedents and outcomes of organizational commitment. Administrative Science Quarterly, 22(1): 46-56.

Udu, A. A. \& Ameh, A. A. (2016). Effects of employee commitment on organizational performance in the banking industry: an evidence from first bank Enugu zonal offices. Scholarly Journal of Business Administration vol. 6 (1)), 1-7.

Wagar, T. (2003). Innovative human resource practices and organizational commitment; an empirical investigation.

Yousef, D. A. (1998). Satisfaction with job security as a predictor of organizational commitment and job performance in a multicultural environment. International Journal of Manpower, 19(3), 184-194. 